\title{
Can a Muslim be an Evolutionist?
}

\author{
Caner Taslaman
}

\subsection{Religious Authority}

"What should a Muslim reject on religious grounds?" Every Muslim denomination affirms the authority of the Quran: every fundamental tenet of faith - such as the almightiness and mercy of God, and the Hereaftermust have a basis in the Quran. A Muslim should reject, then, any claim that contradicts any verse, under all plausible interpretations, of the Quran (one need not bother with strained or exaggerated interpretations). If a claim contradicts a certain interpretation but not another plausible interpretation, it cannot be claimed to conflict with the Quran simpliciter. Since the plausible non-contradicting interpretation may be correct, the claim may not conflict with the Quran.

Most Muslims also accept the authority of the Hadith, a collection of the sayings and actions attributed to the Prophet Mohammed. But the Hadith contains some fabricated statements (hadith mawdu) that are falsely attributed to the Prophet. Some of these fabrications came from Judeo-Christian narratives (referred to as Israilliyyah and Masehiyyah). There is an abundance of Hadiths related to the creation of the universe and life, details which are not given in the Quran. Since many of these

C. Taslaman $(\bowtie)$

Yildiz Technical University, Istanbul, Turkey

(C) The Author(s) 2022

107

K. J. Clark, J. Koperski (eds.), Abrahamic Reflections on

Randomness and Providence, https://doi.org/10.1007/978-3-030-75797-7_6 
Hadiths are rightly disputed, I will restrict my discussion of whether or not the theory of evolution conflicts with Islamic beliefs to the Quran.

Of course, merely not contradicting the Quran does not imply that a claim is true. I often start my speeches, "I believe that the theory of evolution is not in conflict with Islamic belief." But that claim is not about the truth of the theory of evolution. I leave discussions of the truth of evolution to, for example, biologists and geneticists. While I might similarly claim that the helical structure of DNA does not conflict with Islam, I leave the determination of the truth of the claim to, say, biochemists. And when I say that the Quran doesn't conflict with the theory of evolution, I do not mean that the Quran reveals evolution; yet, these two statements are also often mixed up. Likewise, if I were to claim that the helical structure of DNA does not contradict the correct, I would not mean to say that the Quran reveals the helical structure of DNA. I only argue that evolution is compatible with Islam, not that all Muslims must believe in evolution. Moreover, I reject the claim that Islam is incompatible with evolution.

Consider, for example, the (false) claim that the moon is bigger than the sun does not conflict with Islam. Since the Quran doesn't mention the sizes of the sun and the moon, no claim about their relative size could contradict with the Quran. So, although the claim that the moon is larger than the sun has been scientifically discredited, it doesn't contradict with Islam.

Likewise, I will argue, no claim about the emergence of life forms and humans can contradict Islam. Although the Quran clearly asserts that all species of life, including humans, are created by God, it does not reveal how God created. Since the Quran doesn't teach how God created species, the Quran is compatible with evolution.

\subsection{Creation: Processive or INSTANTANEOUS CREATION?}

If a painter were to tell us, "I made this painting," we would understand what he means. We would also know that the painting came into existence through various processes: the painter bought a canvas and dyes, mixed the dyes, stuck the brushes in the dyes and then stroked them on the canvas, and so on. "I made this painting" does not contradict the fact that the painting was made through these processes. Such processes are integral parts of the painter's creation. Likewise, when God says, "I created the heavens" or "I created living beings" or "I created humans," one should 
not assume that such expressions imply immediate, processless creation or instantaneous comings into existence.

According to Islam, everything that we observe around ourselves is a product of God's creation, which is typically involved in various processes. When a Muslim finishes his meal, he says "Alhamdulillah" to thank God for the food. However, prior to becoming a meal, the potatoes on the dish went through several processes - they grew in the field, were picked by a farmer, sold to a grocery, bought by a person, and then cooked. All such processes happen thanks to God's creation of atoms, the earth, life, plants, and time. So a Muslim should not claim that creation through processes contradicts the existence of God. When a Muslim drinks milk with his meal, he might recall: "And, behold, in the cattle there is indeed a lesson for you: We [God] give you to drink of that which is secreted from within their bellies between that which is to be eliminated from the animal's body and lifeblood: milk pure and pleasant to those who drink it" (Quran 16:66). By drinking milk, the grateful Muslim does not reject the facts that the cow ate grass, the grass went through many processes in the cow's body and the milk came to the table via the labors of many people. While the verse never mentions all of these processes, believing that God works through processes does not contradict, "We give you to drink."

Many claim that Quranic descriptions of God's creation such as "He says: Be, and it is" (Kun fa rakun) imply a processless creation of life and humans. ${ }^{1}$ But ordering something to be does not imply instantaneous (non-processive) causation. It implies only that the command (or will) of God was involved in creation. While some translate the Arabic article $f a$ as "immediately" and interpret Kun fa Yakun as "He says: Be, and it immediately is," fa is often understood, in other contexts, as "afterwards, hereupon," implying process.

For example, when "He says: Be, and it is" is used in the narration of the creation of Jesus, the context suggests a processive creation: "Said she: 'O my Sustainer! How can I have a son when no man has ever touched me?' It is answered: 'Thus it is: God creates what He wills when He wills a thing to be, He but says unto it, 'Be' - and it is"' (Quran 3:47). Jesus came into existence by God's order, "Be," yet according to the Quran, his mother carried him in her womb until due time (i.e., processive creation).

${ }^{1}$ The following verses contain the statement "He says: Be, and it is": Surah al-Baqarah, 2:117; Surah Ali-Imran, 3:47, 59; Surah al-An'am, 6:73; Suran an-Nahl, 16:40; Surah Maryam, 19:35; Surah Ya-Seen, 36:82; Suran al-Mu'min, 40-68. 
Moreover, when the statement "He says: Be, and it is" is used for the creation of the universe, many Muslims affirm a processive creation; yet they thoughtlessly claim that the same expression for the creation of humankind implies instantaneousness. There is no reason to interpret the creation of humankind and Adam (like Jesus and the universe) as "instantaneous."

While verses containing $f a$ and "Be!" express the essentiality (but not the immediacy) of God's will, God's creation can be processive. Those who reject evolution because it would require God to create through processes ignore both the Quran's teaching and God's creation.

We can come to appreciate the Might and Art of God through the universe functioning via processive creation. The causal succession of chains of events in the universe is a prerequisite for acquiring scientific knowledge. Through scientific knowledge we have learned about the internal structure of the stars, the atmosphere around the earth, how bees produce honey, and the function of the human. Without appreciating the laws of processive creation, it would be impossible to properly comprehend the actions of God.

\subsection{Creation in Six Stages (Days)}

Some of the earliest objections to the theory of evolution involved opinions about the ages of the universe and the earth. Christians who took a very literal interpretation of Genesis, for example, held that the creation lasted just six days. Even today some Christians hold to "Young Earth Creationism," which claims that the creation of the earth happened no earlier than 10,000 years ago. But, since our focus is Islam, I ask: Can a Muslim accept that the universe is 13.8 billion years and the earth is 4.5 billion years old? I will argue that this scientific calculation of the age of the universe does not contradict Islamic beliefs.

The Christian parallels are not irrelevant since the Quran says the creation of the universe and the earth in "six stages (days)." Do these verses contradict the ages of billions of years of the universe and the earth? In the Quran, the Arabic word used to describe "six stages/days," yawm, has the same etymological roots as the Hebrew word "yom." Likewise, yawm can

${ }^{2}$ The verses where "six stages/days" occurs are: Surah al-Araf, 7:54; Surah Yunus, 10:3; Surad Hud, 11:7; Surah al-Furqan, 25:59; Surah as-Sajdah, 32:4; Surah Qaf, 50:38; Surah al-Hadeed, 57:4. 
mean both "24-hours" and "stage" or "period of time." We find such interpretations in Islamic literature centuries before modern scientific views on the age of the universe. Moreover, in the Quran itself yawm refers to 50,000 years and 1000 years, consistent with a "stage" interpretation. These verses are:

Sajdah, 32:5- He governs all that exists, from the celestial space to the earth; and in the end all shall ascend unto Him on a Day the length whereof will be like a thousand years of your reckoning.

Ma'arij, 70:4- All the angels and all the inspiration ascend unto Him, in a day the length whereof is like fifty thousand years.

Since the Quran doesn't commit Muslims to creation in six literal 24-hour days, the geological and paleontological findings indicating that the universe is billions of years old did not ignite any religion-science clashes in the Islamic world.

\subsection{Creation of Man from Clay}

The most common Muslim rejection of evolution involves the creation of man from clay.

An'am, 6:2- He it is who has created you out of clay, and then has decreed a term for you-a term known only to him. And yet you doubt.

While the creation of Adam (with name explicitly mentioned) from dust is mentioned only once (Surah Al-i Imran, verse 59), several verses mention the creation of man from dust and water (clay). For example: We have created you out of dust (Surah al-Hajj, verse 5); Now, indeed, We create man out of the essence of clay (Surah al-Muminoon, verse 12); He creates you out of dust (Surah ar-Room, verse 20). Since the verses that describe the creation of the first man also describe the creation of all humanity, let us approach a Quranic understanding of the creation of the first man through an understanding of the creation of all humans.

We are often misled by far out interpretations instead of the simplest and clearest explanation that stands before us. What is that simple explanation? Our food comes from animals and plants. When a seed is planted in the soil, it germinates and develops into a full plant by mixing together water and soil (clay, mud); when animals eat these plants, they digest and 
re-generate them into body parts. For example, a corn seed is thrown into the soil, the seed takes water and minerals from the soil and becomes a mature plant, the corn is then fed to a chicken, the chicken modifies the corn and distributes its constituents to its body. Both plants and animals are formed via modifications of the raw materials present in mud. And when we eat animals, their body parts become ours. The raw materials of me, then, are the plants and animals that I eat, which are in essence a processed version of mud. We ourselves are formed by the processing of clay. The body of every single human being is continually formed (created) from body parts of plants and animals. In short, creation from clay is not an instantaneous, completed process. Indeed, every element in our bodies, iron, oxygen, calcium, zinc, and so on, is present in the soil. Without allegorical or strained interpretation, these verses describe the regular, processive creation of all humans from clay. Hence, evolution should not be ruled out because the Quran affirms "creation from clay."

The Quran also describes the "creation from clay" as an initial stage, which "beginning" (badaa) implies the occurrence of other stages:

Makes most excellent everything that He creates. Thus, He begins the creation of man out of clay. Sajdah, 32:7

When someone produces something out of a certain material, he could describe the process by making reference to the material. A sculptor, for example, might say "I made the statue from marble." When we hear such commonly used language, we do not assume that the marble didn't require shaping and polishing. Why, then, assume that "I created men from clay" implies a lack of processes? Pointing to the raw material does not imply no process. If there is no problem understanding a sculptor processing the raw materials into products, there is no problem thinking that God creates through intermediary processes. "Creation from clay," then, is a shorthand specification of the raw materials of every human being, not a denial that the clay becomes a human being through a divinely guided process.

So when Prophet Saleh tells his people "He brought you into being out of the earth" (Quran, Surah Hud, verse 61), nobody takes this verse to mean that people emerge from the earth without the involvement of parents or biological processes. If divine creation implies lack of processes, then should we understand this verse as meaning the immediate creation of the people from earth, which is ludicrous. 
The Muslim, then, rejects the claim that God does not create humans through physical and chemical processes (from clay to animals and plants to humans). God, the Quran tells us, governs all these processes with the intention of creating animals and humans. Biology is the branch of science that tells us how God did it. Theologically speaking, no biological description (correct or not) of the formation of life out of lifeless raw materials (e.g., clay) can contradict creation as taught by Islam.

\subsection{Human Dignity, Common Ancestry}

Muslim's reject evolution on the basis of the theory's claim of common ancestry between humans and animals, particularly with the apes. I often hear rejections of evolution expressed as follows: "My grandfather is not an ape!" However, when asked to specify which verses of the Quran speak against common ancestry, critics have little to say. However, some claim that descent from apes would be against human dignity. In this chapter, I will consider objections related to human dignity.

The establishment of an ancestral relationship between humans and apes does not jeopardize human dignity. In the Quran, Satan is censured for his arrogance in claiming his origins superior to that of man, thereby rising against God. ${ }^{3}$ From this, should we understand that the Quran condemns ancestral arrogance. Rooting human dignity in ancestry lacks a Quranic foundation.

Consider Pharaoh and Abu Lahab: humans share ancestry with them, yet sharing ancestry with wicked people is no detriment to human dignity! If the existence of such wicked people among our species does not diminish our dignity, why would ancestry shared with an animal? Indeed, the fiercest enemies of the Prophet Muhammad, Abu Lahab and Abu Caheel, were his relatives. If being related to a bad person diminished human dignity, it would follow that the Prophet Muhammad lacked dignity. But no Muslim would accept such a claim. Ancestry has nothing to do with dignity. Is the claim of common ancestry of humans with fish or apes worse than the claim of shared ancestry with Pharoah or Abu Lahab?

Indeed, while Pharoah and Abu Lahab are censured in the Quran, fish and apes are not. So why should one feel uncomfortable about sharing ancestry with animals which are not scorned in the Quran, yet feel no

\footnotetext{
${ }^{3}$ Surad Sad, 38:76.
} 
discomfort about sharing ancestry with those that the Quran declares as worse than animals?

The compatibility of evolution with human dignity does not imply that evolution is Islamically correct or that it should be accepted. That would require an assessment of the evidences of biology, geology, paleontology, and so on. Nevertheless, there is no Quranic basis for rejecting evolution from an Islamic perspective on human dignity.

\subsection{Nafsi Wahida: Descent From Adam AND Eve?}

While some Muslims hold that non-human species were created through evolution, humans, they claim, are an exception. However, as we've been arguing, there is no Islamic problem in believing that God created all living beings, including humans, through evolutionary processes. How, then, should we understand the Quran's claim of “creation out of one kind/entity" ( nafsi wahida):

O humankind! Be conscious of your Sustainer, who has created you out of one kind, and out of it created its mate, and out of the two spread abroad a multitude of men and women. (Nisa, 4:1)

Some theologians interpret "one living kind/entity" (nafsi wahida) as the creation of Eve ${ }^{4}$ from Adam's rib and the descent of all humankind from this first couple. However, the Quran says nothing about the creation of Eve from Adam's rib. That belief snuck into Muslim thought from the JudeoChristian tradition (Isra'iliyyat), which contains many apocryphal narratives. Hence, Muslims should not base religious views on such narratives.

This narrative is also exploited for the denigration of women-woman's creation from and for man grounds, some say, the ontological inferiority of women to men. Some also claim that since woman was created from an errant rib, she has an inborn tendency to go astray. Again, the Quran neither contains nor tolerates such sexist arguments. ${ }^{5}$

The creation of humanity out of a single kind is more properly understood as asserting that men and women are members of the same species (Yar 2011, 78-79). So we read in the following verses the Arabic word nafs as meaning "kind":

\footnotetext{
${ }^{4}$ The name "Eve" does not occur in the Quran.

${ }^{5}$ For more on this subject, see Barlas (2002, 133-36).
} 
He creates for you mates out of your own kind (nafs). ${ }^{6}$ Room, 30:21-

he raised up in their midst an apostle from among themselves (nafs). Ali Imran, 3:164-

The first verse emphasizes the creation of mates of the same kind, and the second speaks of messengers of the same kind (the apostles were not chosen from among angels). Since neither mates nor apostles were created from the body parts of humans, the term "creation out of one kind/entity (nafsi wahida)" should be taken to mean "as members of the same, human species."

The Quranic claim that humans are created out of one kind, then, does not imply that Adam was created instantaneously out of the clay and that Eve was created out of Adam's rib (and all subsequent humans created from this first couple). It implies something much simpler-all human beings are of the same species. As such, it doesn't conflict with evolutionary theory. And, so, evolutionary theory does not conflict with Islam properly understood.

\subsection{Theological Agnosticism}

So far, I have attempted to show that the theory of evolution is compatible with belief in God, and that from an Islamic perspective there is no need to oppose this theory. I argued that Quranic terminologies such as "creation from clay" and "nafsi wahida" do not require the rejection of evolution. Moreover, I reject the claim that the Quran teaches or even implies the theory of evolution. Combined, these arguments show that it is impossible to argue for or against the theory of evolution based solely on the content of the Quran. The best stance for a Muslim, then, is to evaluate the scientific-philosophical aspects of the theory independently of religious concerns; that is, Muslims should be theologically agnostic about evolution. By theological agnosticism, I mean that since the Quran neither favors nor rejects the theory, a Muslim should, with respect to theology, be agnostic about whether or not evolution is true; the Quran neither affirms nor denies the truth of evolution. Therefore, a Muslim can and should in good faith focus entirely on the scientific aspects of the theory (safely setting religious considerations aside).

I do not use the term "theological agnosticism" in its common sense of "God is unknowable." The Quran affirms both the existence and

\footnotetext{
${ }^{6}$ See also Surah an-Nahl, 16:72; Surah ash-Shu'ra, 42:11.
} 
attributes of God (such as God's Knowledge and Power). And it reveals the creation of life by God. So a Muslim should not be agnostic about God's existence and some of God's attributes.

So while the Quran reveals that God is Creator, it does not reveal how God created. So, rationally, the Muslim should be theologically agnostic about God's methods, when viewed from a purely religious angle. Indeed, Muslims should be theologically agnostic about every scientific issue that does not conflict with the Quran. So, for example, Muslims should be theologically agnostic about the precise number of continents or planets (let geology and astronomy answer those questions for us). And since the Quran doesn't specify, we should be theologically agnostic about whether species were created independently or evolved from each other (let biology, say, or paleontology tell us).

Theological agnosticism does not imply scientific agnosticism-while Muslim theology does not tell us the number of planets or continents, various sciences do. And theological agnosticism does not imply that a Muslim should be scientifically agnostic about evolution. A Muslim should carefully consider the relevant sciences to determine their rational belief. A Muslim, then, can consider evolution with either prejudice or fear. She has no theological stake on the issues. Muslims should reach their opinions about evolution on the basis of scientific evidence and without any religious concerns, just as they do when assessing theories of light, fluid dynamics, or Einstein's general theory of relativity.

What does the scientific evidence say about the theory of evolution? While there are still issues outstanding, it is the most successful scientific theory of all of it alternatives. Indeed, there is a marvelous beauty in this theory as it relates all living beings to each other and reveals a kind of unity in life.

If God has not revealed an issue to us, it is best to say, "I do not know" (theologically) and turn, again without prejudice or fear, to the relevant sciences.

\subsection{Conclusion}

I have distinguished the question "Can a Muslim be an evolutionist?" from the debate about the correctness of the theory, and focused on the former. I have argued that a Muslim can, without prejudice or fear, accept evolution. The Quran, clearly considered, offers no verses that contradict the theory of evolution. Therefore, a Muslim can believe in evolution. I 
have not claimed that a Muslim must accept evolution. Just as the Quran contains no verse that conflicts with the theory, no verse in the Quran obligates believing in the theory either.

I have defended theological agnosticism about evolution, holding that the acceptance or rejection of evolution is not determined from an Islamic perspective; theologically, Muslims should be agnostic about the theory. Our judgment about the theory, then, should be based on the relevant scientific evidence. So, although I am theologically agnostic about evolution, I am convinced that the theory of evolution is the most successful scientific explanation among its alternatives.

Since the theory of evolution is not in conflict with Islam, Muslim thinkers can relax and approach the topic with open-mindedness, scrutinizing evolution in the light of scientific findings and philosophical evaluations, and thereby arrive at their own considered conclusions about evolution.

\section{BIBLIOGRAPHY}

Barlas, Asma. 2002. Believing Women. In Islam: Unreading Patriarchal Interpretations of the Qur'ān. Austin: University of Texas Press.

Yar, Erkan. 2011. Ruh-beden iliş̧isi açısından insanın bütünlüğ̈̈ sorunu. Ankara: Ankara Okulu Yayınları.

Open Access This chapter is licensed under the terms of the Creative Commons Attribution 4.0 International License (http://creativecommons.org/licenses/ by $/ 4.0 /$ ), which permits use, sharing, adaptation, distribution and reproduction in any medium or format, as long as you give appropriate credit to the original author(s) and the source, provide a link to the Creative Commons licence and indicate if changes were made.

The images or other third party material in this chapter are included in the chapter's Creative Commons licence, unless indicated otherwise in a credit line to the material. If material is not included in the chapter's Creative Commons licence and your intended use is not permitted by statutory regulation or exceeds the permitted use, you will need to obtain permission directly from the copyright holder.

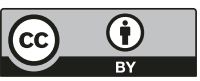

